\title{
Afbakening arbeidsmarktgerichtheid niet-OCW erkende scholing voor STAP regeling
}

Citation for published version (APA):

Künn, A., \& Montizaan, R. (2021). Afbakening arbeidsmarktgerichtheid niet-OCW erkende scholing voor STAP regeling. ROA. ROA Reports No. 007 https://doi.org/10.26481/umarep.2021007

Document status and date:

Published: $14 / 12 / 2021$

DOI:

10.26481/umarep.2021007

Document Version:

Publisher's PDF, also known as Version of record

\section{Please check the document version of this publication:}

- A submitted manuscript is the version of the article upon submission and before peer-review. There can be important differences between the submitted version and the official published version of record.

People interested in the research are advised to contact the author for the final version of the publication, or visit the DOI to the publisher's website.

- The final author version and the galley proof are versions of the publication after peer review.

- The final published version features the final layout of the paper including the volume, issue and page numbers.

Link to publication

\footnotetext{
General rights rights.

- You may freely distribute the URL identifying the publication in the public portal. please follow below link for the End User Agreement:

www.umlib.nl/taverne-license

Take down policy

If you believe that this document breaches copyright please contact us at:

repository@maastrichtuniversity.nl

providing details and we will investigate your claim.
}

Copyright and moral rights for the publications made accessible in the public portal are retained by the authors and/or other copyright owners and it is a condition of accessing publications that users recognise and abide by the legal requirements associated with these

- Users may download and print one copy of any publication from the public portal for the purpose of private study or research.

- You may not further distribute the material or use it for any profit-making activity or commercial gain

If the publication is distributed under the terms of Article $25 \mathrm{fa}$ of the Dutch Copyright Act, indicated by the "Taverne" license above, 
Maastricht University

\section{Afbakening arbeidsmarktgerichtheid niet-OCW erkende scholing voor STAP regeling}

Annemarie Künn-Nelen

Raymond Montizaan

\section{ROA Rapport}

ROA-R-2021/7

Researchcentrum voor Onderwijs en Arbeidsmarkt | ROA Research Centre for Education and the Labour Market / ROA 


\title{
Colofon
}

(c) Researchcentrum voor Onderwijs en Arbeidsmarkt (ROA). Niets uit deze uitgave mag op enige manier worden verveelvoudigd zonder voorafgaande schriftelijke toestemming van de directeur van het ROA.

\author{
Researchcentrum voor Onderwijs en Arbeidsmarkt \\ Postbus 616 \\ 6200 MD Maastricht \\ $\mathrm{T}+31433883647$ \\ $\mathrm{F}+31433884914$ \\ secretary-roa-sbe@maastrichtuniversity.nl \\ www.roa.nl \\ School of Business and Economics \\ Maastricht University \\ Vormgeving \\ ROA secretariaat, Maastricht
}

ISBN: 978-90-5321-602-6

ISSN: 2666-8858

oktober 2021 


\section{Inhoud}

1 Inleiding 1

2 De opbouw van het afbakeningskader 3

2.1 Scholing gericht op het vergroten van het leervermogen 4

2.2 Scholing gericht op het vergroten van basisvaardigheden 5

2.3 Scholing gericht op het vergroten van de algemene inzetbaarheid 6

$\begin{array}{lll}\text { 2.4 Scholing gericht op het vergroten van beroepsspecifieke vaardigheden } \quad 7 & 7\end{array}$

3 Voorwaarden waaraan scholing moet voldoen voor het STAP-budget 9

3.1 Algemene selectiecriteria voor niet-OCW erkende scholing 9

3.2 Voorwaarden waaraan scholing gericht op het vergroten van het leervermogen moet voldoen $\quad 10$

3.3 Voorwaarden waaraan scholing gericht op basisvaardigheden moet voldoen

3.4 Voorwaarden waaraan scholing gericht op algemene inzetbaarheid moet voldoen

3.5 Voorwaarden waaraan scholing gericht op beroepsspecifieke vaardigheden moet voldoen 17

Literatuur

Appendix A

Appendix B 


\section{Inleiding}

Werkenden en werkzoekenden kunnen vanaf 1 maart 2022 een STAP-budget van maximaal 1000 Euro aanvragen voor scholing en ontwikkeling. ${ }^{1}$ STAP staat voor Stimulering ArbeidsmarktPositie. Met het STAP-budget wil de overheid mensen helpen om zich te ontwikkelen tijdens hun loopbaan waardoor zij meer kansen hebben om hun baan te houden of om een nieuwe baan te vinden.

De overheid beoogt daarmee ook dat specifiek risicogroepen (zoals flexwerkers, werkzoekenden, werkenden in beroepen waar minder vraag naar is, en mensen die om financiële redenen geen (bij)scholing kunnen volgen) met het STAP-budget sneller zullen gaan kiezen voor een scholing of cursus, zodat ook zij zich kunnen ontwikkelen tijdens hun loopbaan en in staat zijn om hun positie op de arbeidsmarkt te versterken.

Het STAP-budget vervangt de fiscale aftrek scholingskosten en kan worden gebruikt voor de bekostiging van OCW-erkende scholing als ook voor de bekostiging van niet OCW-erkende scholing. ${ }^{2}$ Het aanbod van niet OCW-erkende scholing is divers. Het betreft zowel gecertificeerde scholing als ook cursussen zonder certificaten en cursussen zonder bewijs van afronding. Daarnaast is een deel van de niet OCW-erkende scholing gericht op professionals, een ander deel gericht op hobbyisten.

Gegeven de doelstelling van STAP, is het echter belangrijk dat alleen scholing gericht op het versterken van de arbeidsmarktpositie gefinancierd kan worden door het STAPbudget. Het ROA heeft daarom in opdracht van het ministerie van Sociale Zaken en Werkgelegenheid (SZW), een afbakeningskader ontwikkeld om de arbeidsmarktgerichtheid van niet OCW-erkende scholing te toetsen.

Bij de ontwikkeling van het afbakeningskader hebben we gebruik gemaakt van wetenschappelijke literatuur waaruit blijkt welke vaardigheden bijdragen aan een sterke arbeidsmarktpositie en hebben we gekeken naar beoordelingssystemen in andere landen (Vlaams opleidingsverlof).

In dit rapport beschrijven we het afbakeningskader. In hoofdstuk 2 wordt een verantwoording gegeven voor de opbouw van het afbakeningskader. Hoofdstuk 3 bevat een gedetailleerd overzicht van de voorwaarden waaraan scholing moet voldoen om volgens het afbakeningskader in aanmerking te komen voor een STAP-budget.

1 Voor meer informatie over het STAP-budget, zie https://www.rijksoverheid.nl/onderwerpen/leven-langontwikkelen/leven-lang-ontwikkelen-financiele-regelingen/stap-budget

2 Op termijn is het ook mogelijk om EVC-trajecten vanuit het STAP-budget te bekostigen. 
In de bijlage is de handleiding 'Afbakening niet-OCW erkende scholing t.b.v. STAP' opgenomen. Deze handleiding is bedoeld voor opleidingsaanbieders en maakt inzichtelijk welk scholingsaanbod zij kunnen laten opnemen in het scholingsregister van STAP. 


\section{De opbouw van het afbakeningskader}

Alle OCW erkende scholing komt via het scholingsregister automatisch in aanmerking voor subsidie vanuit STAP. Het afbakeningskader geldt daarom alleen voor niet-OCW erkende scholing en richt zich op criteria om de arbeidsmarktgerichtheid van deze scholing te beoordelen. Het kader bestaat uit een viertal lagen:

1. Scholing gericht op het vergroten van het leervermogen

2. Scholing gericht op het vergroten van basisvaardigheden

3. Scholing gericht op het vergroten van de algemene inzetbaarheid

4. Scholing gericht op het vergroten van beroepsspecifieke vaardigheden

Het idee achter deze lagen is dat investeringen in duurzame inzetbaarheid allereerst cruciaal afhangen van het leervermogen van mensen (laag 1). Immers, mensen kunnen pas effectief deelnemen aan cursussen, scholing en trainingen als zij ook in staat zijn om te leren. Mensen kunnen vervolgens investeren in basisvaardigheden die noodzakelijk zijn om te kunnen functioneren op de Nederlandse arbeidsmarkt (laag 2). Bovendien kunnen zij investeren in algemene inzetbaarheid door trainingen, scholing en cursussen te volgen die kennis en vaardigheden genereren die in diverse beroepen en sectoren in de Nederlandse arbeidsmarkt te gebruiken zijn (laag 3). Deze vaardigheden zijn uiterst relevant omdat zij ervoor zorgen dat mensen breder inzetbaar worden en ook van beroep kunnen wisselen. Als laatste kunnen werknemers investeren in beroepsspecifieke vaardigheden zodat zij zich in hun beroep verder kunnen ontwikkelen. De vier lagen bestaan naast elkaar, omdat niet iedereen zich in alle lagen hoeft te ontwikkelen.

In Figuur 1 is de opbouw van het afbakeningskader weergegeven. 
Figuur 1

Opbouw afbakeningskader

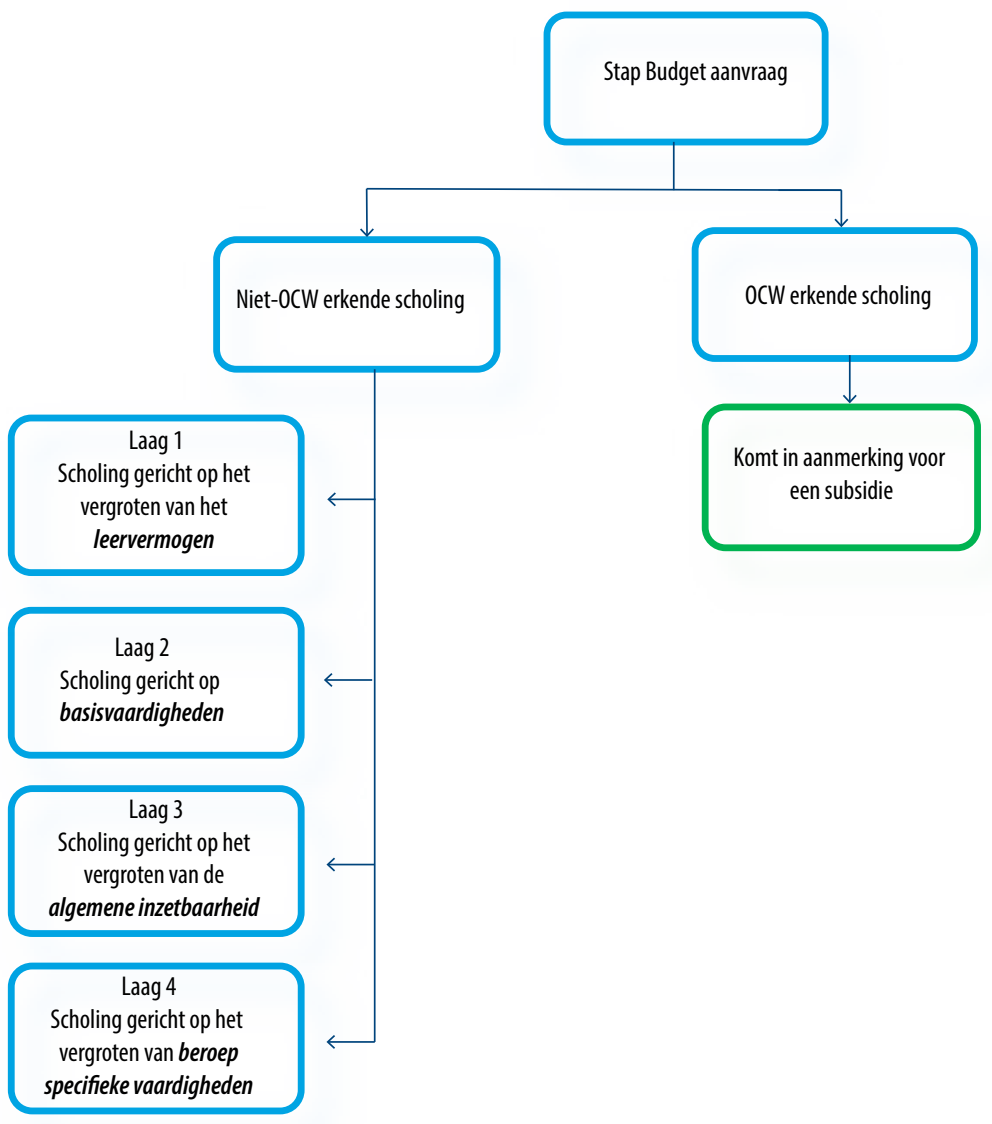

Voor elke laag gelden bepaalde voorwaarden waaraan de scholing moet voldoen voordat de scholing opgenomen mag worden in het scholingsregister voor het STAPbudget. ${ }^{3}$ In de rest van dit hoofdstuk wordt toegelicht waarom deze vier lagen opgenomen zijn in het afbakeningskader.

\subsection{Scholing gericht op het vergroten van het leervermogen}

De arbeidsmarkt is onderhevig aan veranderingen en onzekerheden. Door de flexibilisering van de arbeidsmarkt werken mensen niet langer op één plek gedurende hun loopbaan, maar vinden er veel meer transities plaats (Chkalova 2015). Door de vergrij-

3 In hoofdstuk 3 gaan we in op deze voorwaarden. 
zing en bijbehorende beleidsmaatregelen moet men langer blijven werken en moeten kennis en vaardigheden langer op peil blijven (De Grip, Fouarge, \& Montizaan 2015). Technologische veranderingen zorgen ervoor dat banen verdwijnen en veranderen, waardoor ook de benodigde vaardigheden aan veranderingen onderhevig zijn (Autor \& Salomons 2018). De kennis en vaardigheden die je opdoet tijdens je initiële scholing zijn niet langer voldoende om een leven lang productief te blijven op de arbeidsmarkt. Er is een continue noodzaak tot een leven lang ontwikkelen (De Grip e.a. 2018).

Hoewel een groot deel van de Nederlandse beroepsbevolking deelneemt aan een leven lang ontwikkelen, blijven specifieke groepen achter (Künn e.a. 2018). Zo blijft de trainingsdeelname van ouderen, laagopgeleiden en mensen met tijdelijke arbeidscontracten achter bij die van jongeren, hoogopgeleiden en mensen met een vast contract (e.g., Fouarge e.a. 2013; Cutuli \& Guetto 2013; Addio e.a. 2010; Finegold e.a. 2005). Ook zelfstandigen nemen beduidend minder vaak aan training deel (Kawaguchi 2003). Terwijl voor mensen met een tijdelijk contract geldt dat zij minder trainingsmogelijkheden krijgen, en voor zelfstandigen geldt dat zij vaak de financiële middelen niet hebben, geldt voor met name laagopgeleiden dat zij een lage leermotivatie (Künn e.a. 2018), een laag leervermogen (Heckman 2007) en een lage self-efficacy ten aanzien van leren (Damen e.a. 2013) hebben. Een lagere leermotivatie, leervermogen en self-efficacy ten aanzien van leren blijken vervolgens weer gerelateerd te zijn aan een lagere intentie om aan scholing deel te nemen (Colquitt e.a. 2000; Kyndt \& Baert 2013; Maurer \& Tarulli 1994). En dit verkleint wederom de kans op daadwerkelijke deelname aan scholing (Hazelzet e.a. 2011; Kyndt \& Baert 2013; Maurer e.a. 2003).

Het is dan ook niet verrassend dat er ingezet wordt op het vergroten van het leervermogen om beter om te kunnen gaan met de veranderende en onzekere arbeidsmarkt. Ra e.a. (2019) bevatten de belangrijkste bevindingen uit de literatuur rondom technologische veranderingen en de veranderde vraag naar vaardigheden samen concluderen dat het leervermogen van mensen vergroot moet worden. Dit kan bijvoorbeeld door ervoor te zorgen dat laagopgeleiden het vertrouwen krijgen dat ze kunnen leren (Damen e.a. 2013), en om examenangst te verminderen (Fouarge e.a. 2013).

Onder laag 1 van het afbakeningskader valt daarom scholing gericht op het vergroten van het leervermogen. Hieronder verstaan we onder andere scholing gericht op het vergroten van het self-efficacy ten aanzien van leren (Kirschner 2017, Damen e.a. 2013) en op het aanpakken van faalangst, leeranxiety en examenvrees (Fouarge e.a. 2013). Ook valt scholing gericht op het "leren te leren" onder deze laag (Damen e.a. 2013). Voorbeelden van dergelijke scholing zijn strategisch studeren, methode van lezen en leren, efficiënt en effectief leren. 


\subsection{Scholing gericht op het vergroten van basisvaardigheden}

Uit eerder onderzoek blijkt dat een substantieel deel van de Nederlandse beroepsbevolking laaggeletterd is. Maar liefst 2,5 miljoen volwassenen hebben moeite met (Nederlands) lezen, (Nederlands) schrijven en/of rekenen (Algemene Rekenkamer 2016). Mensen die laaggeletterd zijn op het gebied van lezen, schrijven en rekenen ondervinden vaker dan niet-laaggeletterden obstakels op de arbeidsmarkt en in het dagelijks leven. Vaak blijken zij ook moeite te hebben met digitale vaardigheden (Artero 2020. Daarnaast is het bezit van ICT-basisvaardigheden steeds belangrijker geworden voor succes op de arbeidsmarkt (OECD 2016), en de relevantie is door de Covid-19 situatie alleen maar sterker toegenomen (OECD 2021).

Onder laag 2 van het afbakeningskader onderscheiden we daarom de volgende basisvaardigheden die cruciaal zijn voor alle werkenden en werkzoekenden:

- Rekenvaardigheid

- ICT-basisvaardigheid

- Nederlandse taalvaardigheid eerste taal (NT1)

- Nederlandse taalvaardigheid tweede taal (NT2)

\subsection{Scholing gericht op het vergroten van de algemene inzetbaarheid}

Vaardigheden die relevant zijn voor de algemene inzetbaarheid worden ook wel 21e-eeuwse vaardigheden, vakoverstijgende, of brede vaardigheden genoemd. Deze vaardigheden zijn niet direct aan één vak- of leergebied / baan / beroep te koppelen, maar zijn nodig om te functioneren in de snel veranderende samenleving en arbeidsmarkt. Kenmerkend voor deze vaardigheden is dat zij baankansen en de arbeidsmarktpositie kunnen vergroten in een breed deel van de arbeidsmarkt.

Tabel 1 geeft een classificatie van algemene vaardigheden die de algemene inzetbaarheid vergroten (laag 3 van het afbakeningskader). De classificatie is gebaseerd op Evers, Rush \& Berdrow (1998) die vier competenties onderscheiden die ervoor zorgen dat mensen op de lange termijn inzetbaar blijven. De eerste competentie, zelfmanagement, "is het vermogen om verantwoordelijkheid te nemen voor de eigen prestaties, met inbegrip van het bewustzijn, de ontwikkeling, en de toepassing van de eigen vaardigheden en competenties". Deze competentie heeft dus betrekking op dat mensen hun taken efficient kunnen indelen, hun taken zelf kunnen inplannen, assertiviteit tonen, maar ook dat zij flexibiliteit kunnen tonen, een goed aanpassingsvermogen hebben en optimaal gebruik kunnen maken van input die zij krijgen op hun functioneren. 
De tweede en derde competentie betreft de sociale en leiderschapsvaardigheden. Sociale vaardigheden maken een belangrijk deel uit van de zogenaamde soft-skills waarvan diverse internationale studies hebben aangetoond dat zij een steeds belangrijkere rol spelen voor succes op de arbeidsmarkt (Baclar 2016; Deming 2017). Dit laatste komt onder andere doordat sociale vaardigheden niet eenvoudig door automatiserig kunnen weggesubstitueerd worden (Autor 2015) en dus complementair zijn aan nieuwe technologien. Hetzelfde geldt voor leiderschapsvaardigheden, waarvan Weinberger (2011) aantoonde dat deze significant gecorreleerd zijn met groeiende werkgelegenheid, betere baankansen en doorgroeimogelijkheden.

\section{Tabel 1}

Classificatie en voorbeelden algemene competenties

\begin{tabular}{|l|l|l|l|}
\hline Zelf-management & Sociale vaardigheden & $\begin{array}{l}\text { Managen van mensen en } \\
\text { taken }\end{array}$ & $\begin{array}{l}\text { Innovatieve vaardigheden } \\
\text { en analytische } \\
\text { vaardigheden }\end{array}$ \\
\hline $\begin{array}{l}\text { Stress en time } \\
\text { management }\end{array}$ & Samenwerking & $\begin{array}{l}\text { Leiderschaps/ } \\
\text { management } \\
\text { vaardigheden }\end{array}$ & $\begin{array}{l}\text { Vaardigheden gericht op } \\
\text { ondernemerschap }\end{array}$ \\
\hline $\begin{array}{l}\text { Flexibiliteit } \\
\text { Aanpassingsvermogen }\end{array}$ & $\begin{array}{l}\text { Communicatie } \\
\text { Interculturele } \\
\text { vaardigheden } \\
\text { Omgaan met conflicten }\end{array}$ & $\begin{array}{l}\text { Onderhandelen } \\
\text { Collicitatievaardigheden denken }\end{array}$ & $\begin{array}{l}\text { Ideeën omzetten in actie } \\
\text { en oplossingen }\end{array}$ \\
\hline $\begin{array}{l}\text { Ongaan met } \\
\text { Assertiviteit }\end{array}$ & Feedback geven & $\begin{array}{l}\text { Probleemoplossend } \\
\text { vermogen }\end{array}$ \\
\hline $\begin{array}{l}\text { Omgaan met (kritische) } \\
\text { feedback }\end{array}$ & Plannen van taken van & Kritisch denken \\
\hline $\begin{array}{l}\text { Plannen van eigen taken } \\
\text { andere mensen }\end{array}$ & & Onderzoeksvaardigheden \\
\hline
\end{tabular}

Innovatieve vaardigheden en analytische vaardigheden vergroten de algemene inzetbaarheid doordat de toenemende digitalisering, automatisering en robotosering leidt tot een grotere vraag naar geschoolde werknemers die uitblinken in abstracte en nietroutinematige taken waarbij probleemoplossend vermogen, intuïtie, creativiteit, en kritisch denken een belangrijke rol spelen (Autor 2015).

\subsection{Scholing gericht op het vergroten van beroepsspecifieke vaardigheden}

Naast basisvaardigheden en vaardigheden gericht op de algemene inzetbaarheid, is het ook van groot belang dat mensen een hoog niveau aan beroepsspecifieke vaardigheden bezitten (laag 4 van het afbakeningskader). Aarts, \& Künn-Nelen (2019) laten door middel van een vignetten experiment onder 1100 Nederlandse werkgevers zien dat de kwaliteit van beroepsspecifieke vaardigheden nog steeds als de belangrijkste 
factor wordt gezien door werkgevers om een sollicitant aan te nemen. Dezelfde studie laat echter ook zien dat sollicitanten niet alleen moeten inzetten op het verkrijgen van beroepsspecifieke vaardigheden. Vooral een combinatie van beroepsspecifieke vaardigheden en vaardigheden gericht op algemene inzetbaarheid wordt door werkgevers als doorslaggevend ervaren. Scholing moet derhalve gericht zijn op het gecombineerd investeren in basisvaardigheden, vaardigheden gericht op algemene inzetbaarheid, alsmede beroepsspecifieke vaardigheden.

Scholing van deze vaardigheden zal ertoe bijdragen dat de arbeidsmarktpositie van kwetsbare groepen kan worden verbeterd doordat hun afstand tot de arbeidsmarkt wordt verkleind, en er een betere afstemming tussen vraag en aanbod op de arbeidsmarkt onstaat doordat een grotere pool kandidaten met de juiste competenties voor openstaande vacatures wordt gecreërd. 


\section{Voorwaarden waaraan scholing moet voldoen voor het STAP-budget}

In dit hoofdstuk geven we allereerst enkele algemene voorwaarden waaraan de nietOCW erkende scholing moet voldoen. Daarna geven we per laag nog aanvullende voorwaarden waaraan de scholing moet voldoen.

\subsection{Algemene selectiecriteria voor niet-OCW erkende scholing}

Om voor registratie in het scholingsregister van STAP in aanmerking te komen moet niet-OCW erkende scholing voldoen aan algemene en specifieke selectiecriteria. In deze paragraaf volgen 4 algemene selectiecriteria met betrekking tot de scholingsvorm. Daarnaast volgen nog 3 algemene criteria waaraan voldoen moet worden. De specifieke selectiecriteria worden per laag uitgewerkt in paragrafen 3.2 tot en met 3.5.

- Pure hobby cursussen komen niet in aanmerking voor de STAP-regeling. In de beslisbomen wordt daarom op twee plekken gesproken over hobby's. De eerste keer bij de doelgroepen (hobbyisten), en de tweede keer, wanneer er geen doelgroep gedefinieerd is, bij de inhoud van de scholing. Onder hobby's verstaan wij een in het algemeen ontspannende activiteit die men met enige regelmaat in de vrije tijd uitoefent en niet wordt uitgeoefend om de arbeidsmarktpositie te verbeteren. Volgens deze definitie volgen hobbyisten dus cursussen in hun eigen tijd waarvan zij de opgedane kennis niet gebruiken in hun arbeid.

- Bedrijfsgerichte cursussen komen niet in aanmerking voor de STAP-regeling. Het STAP-budget is bedoeld voor het vergroten van brede duurzame inzetbaarheid en niet ter vervanging van scholing die noodzakelijk is voor de uitoefening van de functies of de voortzetting van de huidige arbeidsovereenkomst bij de huidige organisatie waar een persoon werkzaam is.

- Leerabonnementen komen niet in aanmerking voor de STAP-regeling. Nadat een leerabonnement is betaald, kan men zelf bepalen welke specifieke scholing gevolgd wordt. Het is dan niet langer mogelijk om de arbeidsmarktgerichtheid van de scholing te toetsen.

- Niet-OCW erkende scholing met een coaching component kan in aanmerking komen voor de STAP-regeling. ${ }^{4}$ Een cursus komt uitsluitend in aanmerking voor de STAP-regeling als uit de beschrijving van de scholing blijkt dat de coaching compo-

4 We sluiten aan bij de NOBCO-definitie die stelt dat coaching een gestructureerd en doelgericht proces is, waarbij de coach op interactieve wijze de gecoachte aanzet tot effectief gedrag door: bewustwording en persoonlijke groei, het vergroten van zelfvertrouwen en het exploreren, ontwikkelen en toepassen van eigen mogelijkheden. 
nent de helft of minder van de cursustijd in beslag neemt. ${ }^{5}$ Indien de coaching component meer dan de helft van de tijd uitmaakt die men aan de cursus besteedt, dan komt deze niet in aanmerking voor de STAP-regeling.

Daarnaast gelden de volgende algemene voorwaarden:

- De beschrijving van de scholing moet het mogelijk maken de beslisbomen zoals opgenomen in de Handleiding 'Afbakening niet-OCW erkende scholing t.b.v. STAP' te doorlopen. Indien er niet voldoende informatie is om de beslisbomen te doorlopen, worden de cursussen, scholing of trainingen niet toegestaan binnen STAP.

- STAP is bedoeld voor scholing. Daaronder vallen alle kosten die door de opleider in rekening worden gebracht voor het volgen van de opleiding of training. Hieronder vallen dus niet op zichzelf staand cursusmateriaal (o.a. studieboeken die niet zijn voorgeschreven bij scholing, of studiemateriaal zonder dat een curicculum is opgesteld om het materiaal te bestuderen of cursusmateriaal waarbij geen begeleiding wordt aangeboden bij het studeren). ${ }^{6}$

- Scholing komt alleen in aanmerking voor de STAP-regeling als er bewijs geleverd wordt van deelname aan de cursus.

Voor E-learning gelden daarbij dezelfde voorwaarden als voor de meer traditionele vormen van scholing.

\subsection{Voorwaarden waaraan scholing gericht op het vergroten van het leervermogen moet voldoen}

Scholing gericht op het vergroten van het leervermogen is relevant om risicogroepen weer aan het leren te krijgen. Leervermogen heeft te maken met het effectief kunnen opnemen van nieuwe kennis of het aanleren van vaardigheden. Door het vergroten van het leervermogen zal iemand dit gemakkelijker doen. Leervermogen hangt cruciaal af van de motivatie om te leren (die o.a. door faalangst, leerangst, en stress beperkt wordt), de mate waarin mensen nieuwe kennis kunnen eigen maken en in welke mate zij de kennis kunnen toepassen.

De scholing gericht op leervermogen moet zich richten op minstens één van de volgende onderwerpen om in aanmerking te komen voor een STAP-budget (laag 1):

- het zelfbeeld vergroten (zoals persoonlijke groei of persoonlijke ontwikkeling t.b.v. vermindering stress, zelfvertrouwen)

5 En wordt de beslissing of de scholing al dan niet valt onder de STAP-regeling genomen op basis van andere kenmerken van de scholing.

6 Zie voor de regelgeving omtrent de subsidiabele kosten van de scholing de 'Subsidieregeling STAP-budget' (https://www.rijksoverheid.nl/documenten/kamerstukken/2021/04/01/bijlage-1-subsidieregeling-stapbudget). 
- angsten aanpakken die het leren belemmeren (zoals faalangst, leerangst, examenvrees)

- leerstrategieën aanleren (zoals methoden van leren en lezen, efficiënt en effectief leren, slim leren op de werkplek)

De enige additionele eis die aan deze scholing wordt gesteld, is dat de scholing maximaal 50\% van de scholingstijd uit coaching mag bestaan (zie paragraaf 3.1).

Zie Figuur 2 voor de beslisboom voor scholing gericht op het vergroten van het leervermogen. 


\section{Figuur 2}

Beslisboom scholing gericht op het vergroten van het leervermogen

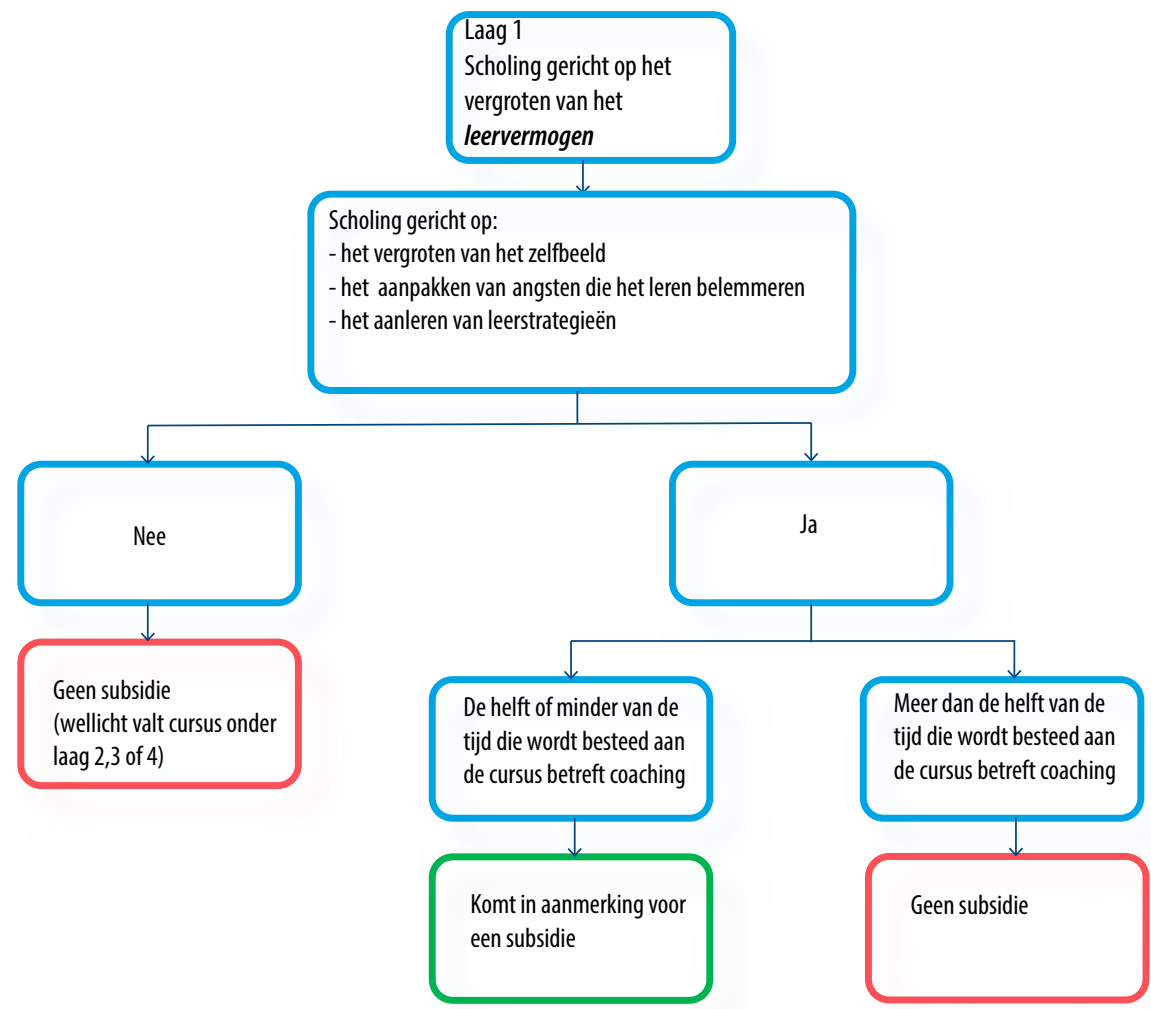

\subsection{Voorwaarden waaraan scholing gericht op basisvaardigheden moet voldoen}

Basisvaardigheden zijn relevant voor alle werkenden en zijn cruciaal om inzetbaar te zijn in de huidige en toekomstige arbeidsmarkt. Onder basisvaardigheden worden uitsluitend de volgende vaardigheden gerekend (laag 2):

- Rekenvaardigheid

- ICT-basisvaardigheid

- Nederlandse taalvaardigheid eerste taal (NT1)

- Nederlandse taalvaardigheid tweede taal (NT2) 
De volgende restricties gelden:

- De scholing moet in detail expliciet maken welke van de vaardigheden zoals vermeld in beslisboom 3 worden aangeleerd.

- Voor rekenvaardigheid geldt dat scholing gericht is op het behalen van een maximaal $2 \mathrm{~F}$ niveau.

- Onder basis ICT-vaardigheden wordt verstaan: het gebruik van computers om informatie op te vragen, te beoordelen, op te slaan, te produceren, te presenteren en uit te wisselen, en om via internet te communiceren en deel te nemen aan samenwerkingsnetwerken. ${ }^{8}$ Zodra de scholing van basis ICT vaardigheden hieraan niet voldoet, komt de scholing niet in aanmerking voor STAP. Scholing gericht op meer geavanceerde ICT / technologische vaardigheden valt onder laag 3 of 4 .

- Voor Nederlandse taalvaardigheid geldt dat scholing gericht is op het behalen van een maximaal $2 \mathrm{~F}$ niveau. ${ }^{9}$

- Maximaal 50\% van de scholingstijd mag uit coaching bestaan.

Zie Figuur 3 voor de beslisboom voor het afbakenen van niet-OCW erkende scholing gericht op het vergroten van basisvaardigheden.

7 Zie https://www.rijksoverheid.nl/onderwerpen/taal-en-rekenen/referentiekader-taal-en-rekenen voor aanvullende informatie.

8 Sleutelcompetenties voor een leven lang leren - Een Europees kader. Luxemburg: Bureau voor officiële publicaties der Europese Gemeenschappen, 2007

9 Cursussen die taalvaardigheden trainen op een hoger niveau kunnen vallen onder laag 3 of 4 , afhankelijk van de beroepsgerichtheid. 
Figuur 3

Beslisboom: basisvaardigheden

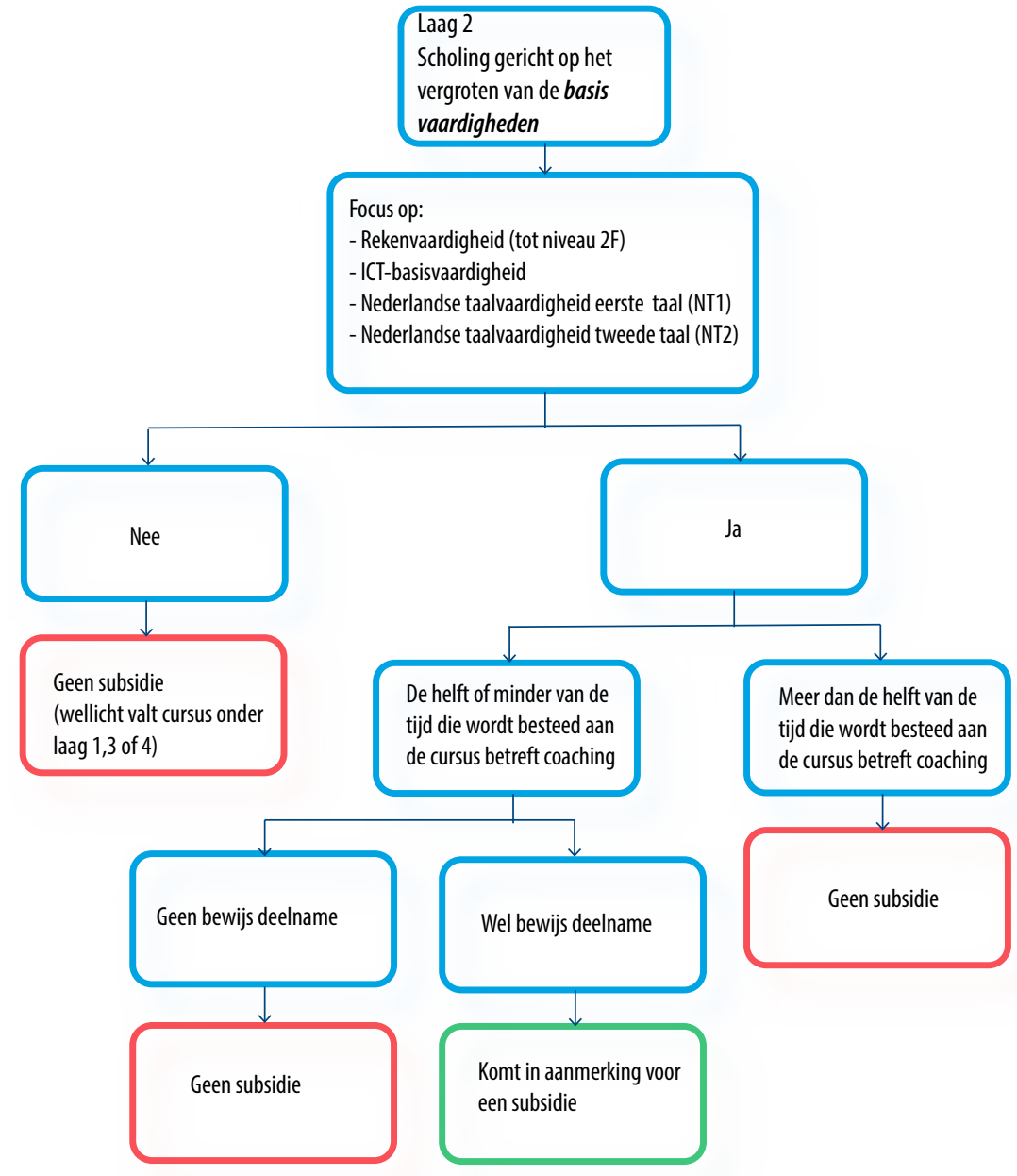

\subsection{Voorwaarden waaraan scholing gericht op algemene inzetbaarheid moet voldoen}

Ook voor niet-OCW erkende scholing gericht op het vergroten van vaardigheden die de algemene inzetbaarheid op de arbeidsmarkt vergroten, gelden een aantal aanvullende eisen (laag 3 ). Zie Figuur 4 voor de beslisboom voor het afbakenen van niet-OCW erkende scholing gericht op het vergroten van deze vaardigheden. 
- Allereerst moet de scholing gericht zijn op het vergroten van de vaardigheden die gerelateerd zijn aan de generieke competenties die zijn omschreven in Tabel 1. De competenties zijn:

1) Verbeteren van zelfmanagement

2) Verbeteren van sociale vaardigheden

3) Efficiënter managen van mensen en taken

4) Verbeteren van innovatieve vaardigheden en analytische vaardigheden

- Er moet getoetst worden of er een duidelijke doelgroep omschreven wordt in de omschrijving van de scholing. Als de doelgroep hobbyisten betreft, valt de cursus direct af. Zodra deze ondernemers, carrière switchers, mensen met professionele ambities of professionals werkzaam op het gebied van de cursus bevatten kan door worden gegaan naar de volgende stap in de beslisboom.

- In het incidentele geval dat de doelgroep niet expliciet gespecificeerd is (wat kan voorkomen als een scholing meerdere doelgroepen tegelijkertijd aanspreekt), kan eveneens worden doorgegaan naar de volgende stap in de beslisboom. In dit geval moet dan wel extra aandacht in de volgende stap van de beslisboom worden besteed aan of het doel daadwerkelijk gericht is op professionele werkzaamheden en of carrièregericht is.

- Na de beschrijving van de doelgroep wordt het doel in detail getoetst. Als niet expliciet vermeld staat dat deze gericht is op specifieke professionele werkzaamheden of carrièregericht is, dan komt de scholing niet in aanmerking voor de STAP-regeling. Het is niet voldoende alleen te beschrijven dat werkzaamheden/ carrière een relevant doel zijn. De omschrijving van de scholing moet specifiek benoemen om welke werkzaamheden of welke aspecten van de carrière het gaat en hoe de opgedane vaardigheden hiertoe direct aan bijdragen.

- Maximaal 50\% van de scholingstijd mag uit coaching bestaan. 


\section{Figuur 4}

Beslisboom: algemene inzetbaarheid op de arbeidsmarkt

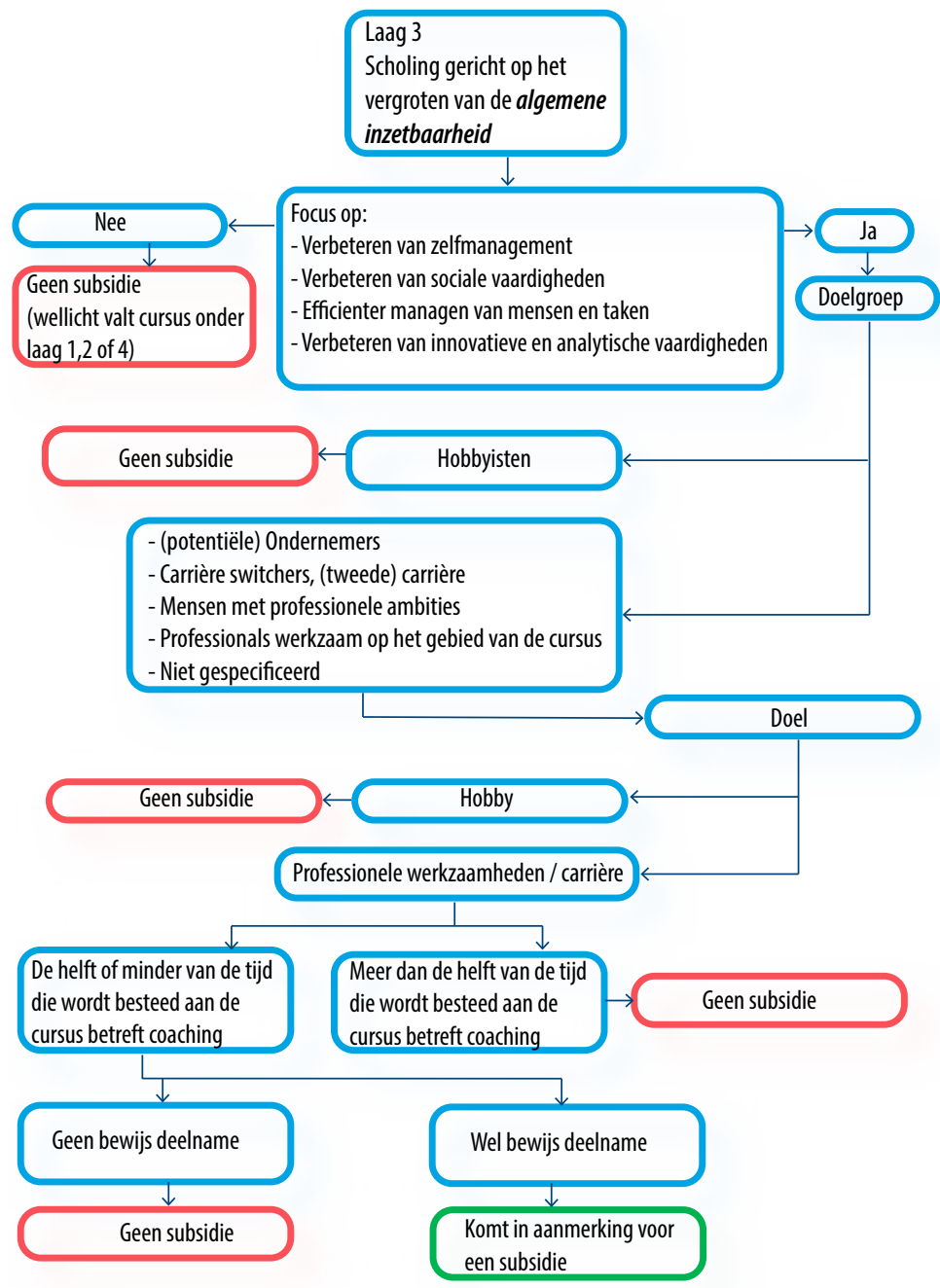




\subsection{Voorwaarden waaraan scholing gericht op beroepsspecifieke vaardigheden moet voldoen}

Om voor registratie in het scholingsregister van STAP in aanmerking te komen moet niet-OCW erkende scholing gericht op beroepsspecifieke vaardigheden voldoen aan de volgende specifieke selectiecriteria (zie de beslisboom in Figuur 5).

- Allereerst wordt vastgesteld of de scholing beroepsspecifieke vaardigheden traint. Indien dit niet het geval is, komt de scholing niet in aanmerking voor het STAPbudget, tenzij deze onder één van de andere lagen kan worden ondergebracht van het afbakeningskader.

- Vervolgens wordt getoetst of er een duidelijke doelgroep omschreven wordt in de omschrijving van de scholing. Als de doelgroep hobbyisten betreft, valt de cursus direct af. Daarentegen, zodra deze ondernemers, carrière switchers, mensen met professionele ambities of professionals werkzaam op het gebied van de cursus bevatten, kan door worden gegaan naar de volgende stap in de beslisboom. Dit laatste geldt ook als de doelgroep in incidentele gevallen niet expliciet gespecificeerd is, onder voorbehoud dat het doel in de volgende stap van de beslisboom dan wel streng wordt beoordeeld.

- Na de beschrijving van de doelgroep wordt het doel getoetst. Als niet expliciet vermeld staat dat deze op beroepsspecifieke vaardigheden gericht is, dan komt de scholing niet in aanmerking. Het is niet voldoende alleen te beschrijven dat werkzaamheden/ carrière een relevant doel zijn. De scholing moet specifiek benoemen om welke werkzaamheden of welke aspecten van de carrière het gaat en hoe de opgedane vaardigheden hiertoe direct aan bijdragen.

- Maximaal 50\% van de scholingstijd mag uit coaching bestaan. 


\section{Figuur 5}

Beslisboom: Beroepsspecifieke vaardigheden

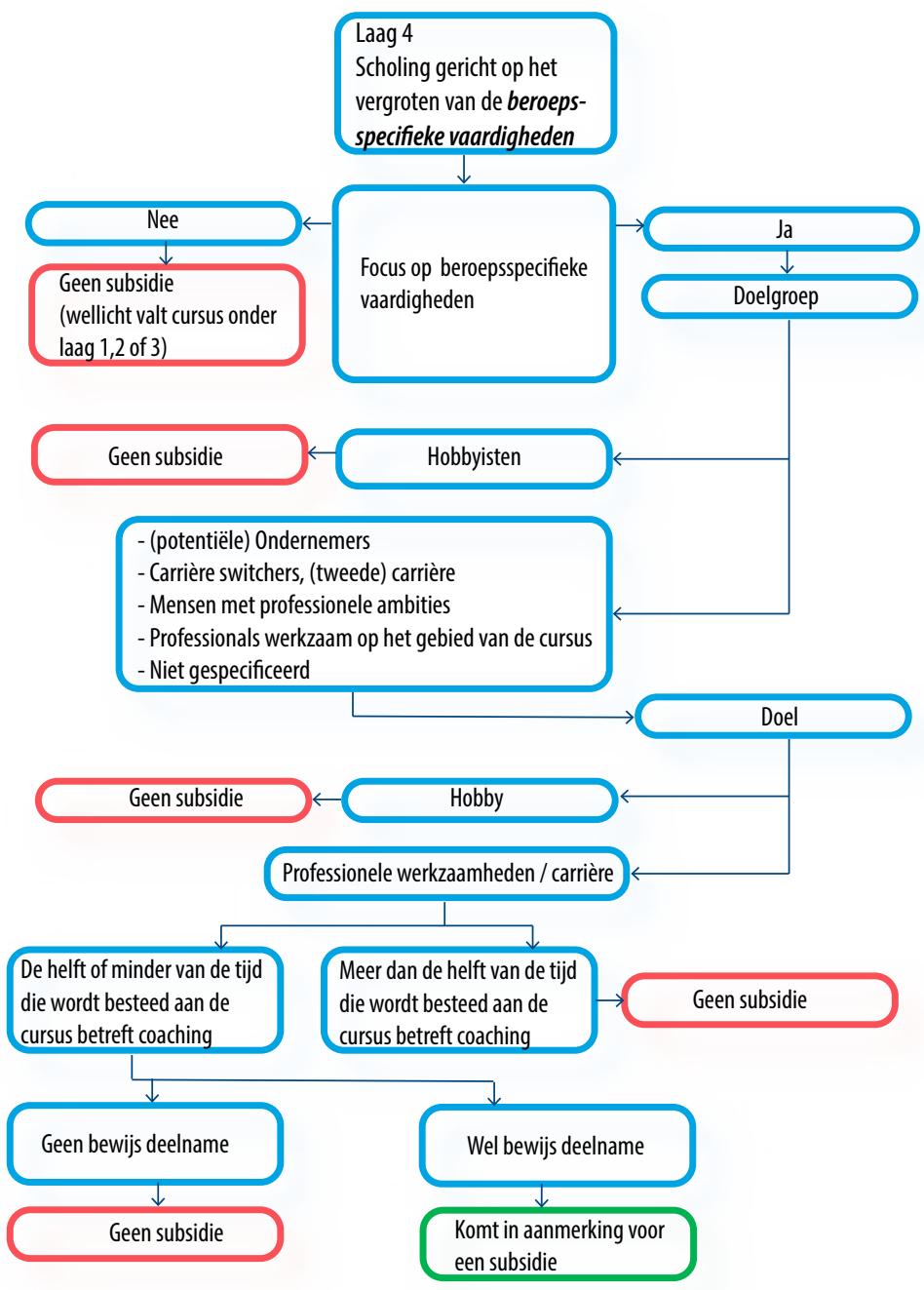




\section{Literatuur}

Aarts, B., \& Künn-Nelen, A. (2019). 'Employability: the employers' perspective Using a stated-preferences experiment to gain insights into employers' preferences for specific competencies' $\mathrm{ROA}$ Rapport ROA-R-2019/6.

Addio, A.D., Keese, M. and Whitehouse, E. (2010). Population ageing and labour markets, Oxford Review of Economic Policy, 26(4), 613-635.

Algemene Rekenkamer (2016). Aanpak van laaggeletterdheid.

Artero, J. M., Borra, C., \& Gómez-Alvarez, R. (2020). Education, inequality and use of digital collaborative platforms: The European case. The Economic and Labour Relations Review, 31(3), 364-382.

Autor D.H. (2015). "Why Are There Still So Many Jobs? The History and Future of Workplace Automation,"Journal of Economic Perspectives, 29, 3-30.

Autor, D., \& Salomons, A. (2018). Is automation labor-displacing? Productivity growth, employment, and the labor share (No. w24871). National Bureau of Economic Research.

Balcar, J. (2016). Is it better to invest in hard or soft skills?. The Economic and Labour Relations Review, 27(4), 453-470.

Chkalova, K., Goudswaard, A., Sanders, J., \& Smits, W. (2015). Dynamiek op de Nederlandse arbeidsmarkt: de focus op flexibilisering. Centraal Bureau voor de statistiek, Den Haag.

Colquitt, J.A., Lepine, J.A. \& Noe, R.A. (2000). Toward an integrative theory of training motivation: a meta-analytic path analysis of 20 years of research, Journal of Applied Psychology, 85(5), 678-707.

Cutuli, G., \& Guetto, R. (2013). Fixed-term contracts, economic conjuncture, and training opportunities: a comparative analysis across European labour markets. European Sociological Review, 29(3), 616-629.

De Grip, A., Belfi, B., Fouarge, D., Künn, A., Peeters, T., \& Poulissen, D. (2018). Levenslang leren en competentieontwikkeling (No. o08). Maastricht University, Research Centre for Education and the Labour Market (ROA).

De Grip, A., Fouarge, D., \& Montizaan, R. (2015). Goede inzetbaarheid oudere medewerkers vereist beter HR-beleid. Netspar Brief, 4.

Deming, D. J. (2017). The growing importance of social skills in the labor market. The Quarterly Journal of Economics, 132(4), 1593-1640.

Edzes, A., Venhorst, V., \& van Dijk, J. (2015). Grensoverschrijdende arbeidsmarkt: Voorbij de romantiek. Rijnland in de regio: Onderzoek en activiteiten van Stenden Hogeschool en het Alfa-college in de noordelijke Nederlands-Duitse grensregio. Leeuwarden: Stenden Hogeschool/Alfa-college.

Evers, F.T., \& Rush, J.C. \& Berdrow, I. (1998). The Bases of Competence: Skills for Lifelong Learning and Employability, San Francisco: Jossey-Bass. 
Finegold, D., Levenson, A., \& Van Buren, M. (2005). Access to training and its impact on temporary workers. Human Resource Management Journal, 15(2), 66-85.

Fouarge, D., Schils, T., \& De Grip, A. (2013). Why do low-educated workers invest less in further training?. Applied Economics, 45(18), 2587-2601.

Hattie, J. (2009). Visible learning. A synthesis of over 800 meta-analyses relating to achievement. New York, NY: Routledge.

Hazelzet, A., Sanders, J., Langelaan, S., Giesen, F. and Keijzer, L. (2011). Stimuleren van scholing bij lager opgeleide werknemers, TNO, Hoofddorp.

Huijts, T. (2021). Groot verschil in laaggeletterdheid per gemeente. Economisch Statistische Berichten, 4798(106), 303-303.

Kawaguchi, D. (2003). Human capital accumulation of salaried and self-employed workers. Labour economics, 10(1), 55-71.

Künn, A., Poulissen, D., van Eldert, P., Fouarge, D., \& de Grip, A. (2018). Leren onder werkenden met een kwetsbare positie op de arbeidsmarkt. ROA-R-2018/5, Maastricht University, Research Centre for Education and the Labour Market.

Kyndt, E. \& Baert, H. (2013). Antecedents of employees' involvement in work-related learning: a systematic review, Review of Educational Research, 83(2), 273-313.

Maurer, T.J. \& Tarulli, B.A. (1994). Investigation of perceived environment, perceived outcome, and person variables in relationship to voluntary development activity by employees, Journal of Applied Psychology, 79(1), 3-14.

Maurer, T.J., Weiss, E.M. \& Barbeite, F.G. (2003). A model of involvement in work-related learning and development activity: the effects of individual, situational, motivational and age variables, Journal of Applied Psychology, 88(4), 707-724.

OECD (2016). ICTS and Jobs: Complements or Substitutes?, OECD Digital Economy Papers, 259, Paris: OECD Publishing.

Onderwijsraad (2018). Internationalisering in beeld 2018. Den Haag: Onderwijsraad.

Ra, S., Shrestha, U., Khatiwada, S., Yoon, S. W., \& Kwon, K. (2019). The rise of technology and impact on skills. International Journal of Training Research, 17(sup1), 26-40. 


\section{Appendix A \\ Handleiding beoordelingssysteem arbeidsmarktgerichtheid niet-OCW erkende scholing in het kader van de STAP-regeling}

Om voor registratie in het scholingsregister van STAP in aanmerking te komen moet niet-OCW erkende scholing voldoen aan algemene en specifieke selectiecriteria. In deze Appendix beschrijven we:

1. Enkele algemene richtlijnen voor de beoordeling van niet-OCW erkende scholing.

2. Vier algemene selectiecriteria met betrekking tot de scholingsvorm

3. Drie algemene voorwaarden besproken waaraan scholing moet voldoen.

De specifieke selectiecriteria worden verder per laag uitgewerkt in de beslisbomen.

Voor de verantwoording, achtergrond en toelichting van de beslisbomen verwijzen wij naar het rapport 'Afbakening arbeidsmarktgerichtheid niet-OCW erkende scholing voor STAP-regeling'.

1. De algemene richtlijnen voor de beoordeling van niet-OCW erkende scholing zijn:

- Niet alleen naar titel kijken maar ook naar cursusinhoud, inclusief doelgroepen, het doel en trainingsvormen.

- Bepaal eerst de competentiegroep: laag 1, laag 2, laag 3 of laag 4.

- Indien er niet voldoende informatie is om de checklist in te kunnen vullen, komt de scholing niet in aanmerking voor STAP.

2. De vier algemene selectiecriteria ten aanzien van de scholingsvorm zijn:

- Pure hobby cursussen komen niet in aanmerking voor de STAP-regeling. In de beslisbomen wordt daarom op twee plekken gesproken over hobby's. De eerste keer bij de doelgroepen (hobbyisten), en de tweede keer, wanneer er geen doelgroep gedefinieerd is, bij de inhoud van de scholing. Onder hobby's verstaan wij een in het algemeen ontspannende activiteit die men met enige regelmaat in de vrije tijd uitoefent en niet wordt uitgeoefend om de arbeidsmarktpositie te verbeteren. Volgens deze definitie volgen hobbyisten dus cursussen in hun eigen tijd waarvan zij de opgedane kennis niet gebruiken in hun arbeid.

- Bedrijfsgerichte cursussen komen niet in aanmerking voor de STAP-regeling. Het STAP-budget is bedoeld voor het vergroten van brede duurzame inzetbaarheid en niet ter vervanging van cursussen die de werknemer ook had moeten volgen om bij zijn / haar organisatie te blijven werken.

- Leerabonnementen komen niet in aanmerking voor de STAP-regeling. 
- Niet-OCW erkende scholing die een coaching component bevatten kunnen in aanmerking komen voor de STAP-regeling. ${ }^{10}$ Een cursus komt uitsluitend in aanmerking voor de STAP-regeling als uit de beschrijving van de scholing blijkt dat de coaching component de helft of minder van de cursustijd in beslag neemt." Indien de coaching component maximaal de helft van de tijd uitmaakt die men aan de cursus besteedt, dan komt deze niet in aanmerking voor de STAP-regeling.

3. Er gelden de volgende drie algemene voorwaarden:

- De beschrijving van de scholing moet het mogelijk maken de beslisbomen zoals opgenomen in de Handleiding 'Afbakening niet-OCW erkende scholing t.b.v. STAP' te doorlopen. Indien er niet voldoende informatie is om de beslisbomen te doorlopen, worden de cursus, scholing of trainingen niet toegestaan binnen STAP.

- STAP is bedoeld voor cursus, scholing of trainingen, dus niet voor cursusmateriaal zonder onderwijs (o.a. studieboeken die niet zijn voorgeschreven bij scholing, of studiemateriaal zonder dat een curicculum is opgesteld om het materiaal te bestuderen of cursusmateriaal waarbij geen begeleiding wordt aangeboden bij het studeren).

- Cursussen, scholing of trainingen komen alleen in aanmerking voor de STAP-regeling als er bewijs geleverd wordt van deelname aan de cursus.

Voor E-learning gelden daarbij dezelfde voorwaarden als voor de meer traditionele vormen van scholing.

10 We sluiten aan bij de NOBCO-definitie die stelt dat coaching een gestructureerd en doelgericht proces is, waarbij de coach op interactieve wijze de gecoachte aanzet tot effectief gedrag door: bewustwording en persoonlijke groei, het vergroten van zelfvertrouwen en het exploreren, ontwikkelen en toepassen van eigen mogelijkheden.

11 De beslissing of de scholing al dan niet onder de STAP-regeling valt wordt dan genomen op basis van het succesvol doorlopen van de andere stappen van de beslisboom. 


\section{Figuur 1}

Opbouw afbakeningskader

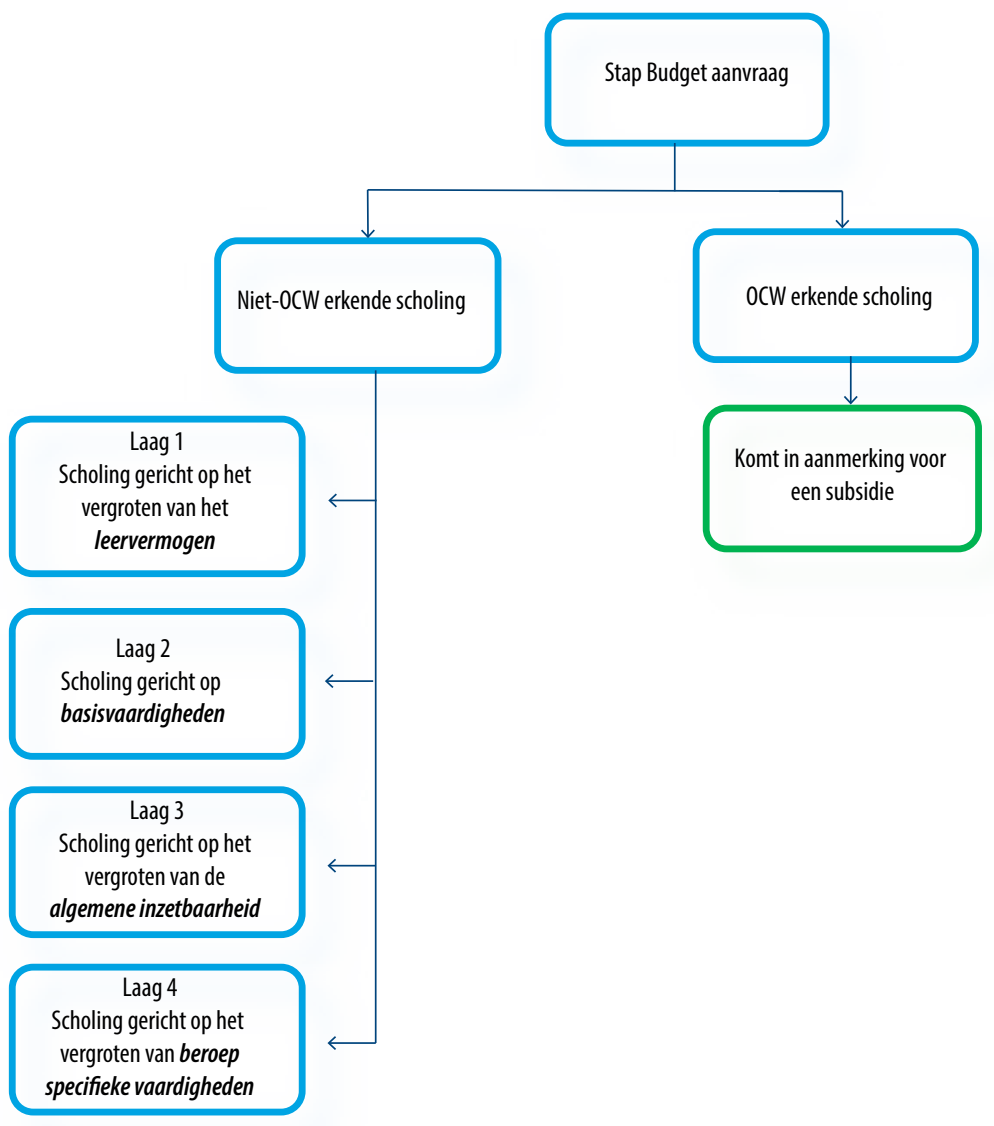




\section{Figuur 2}

Beslisboom scholing gericht op het vergroten van het leervermogen

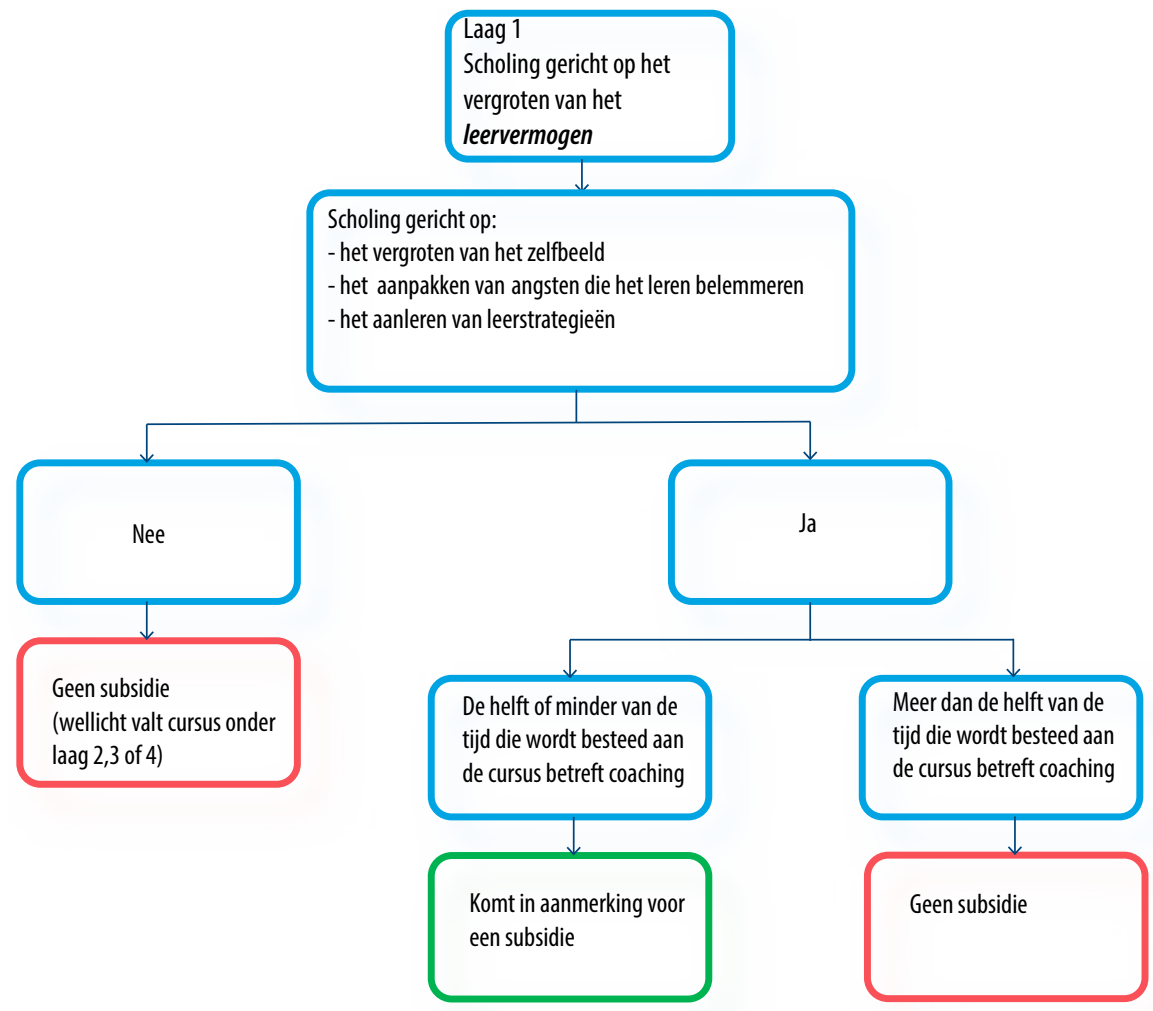




\section{Figuur 3}

Beslisboom: basisvaardigheden

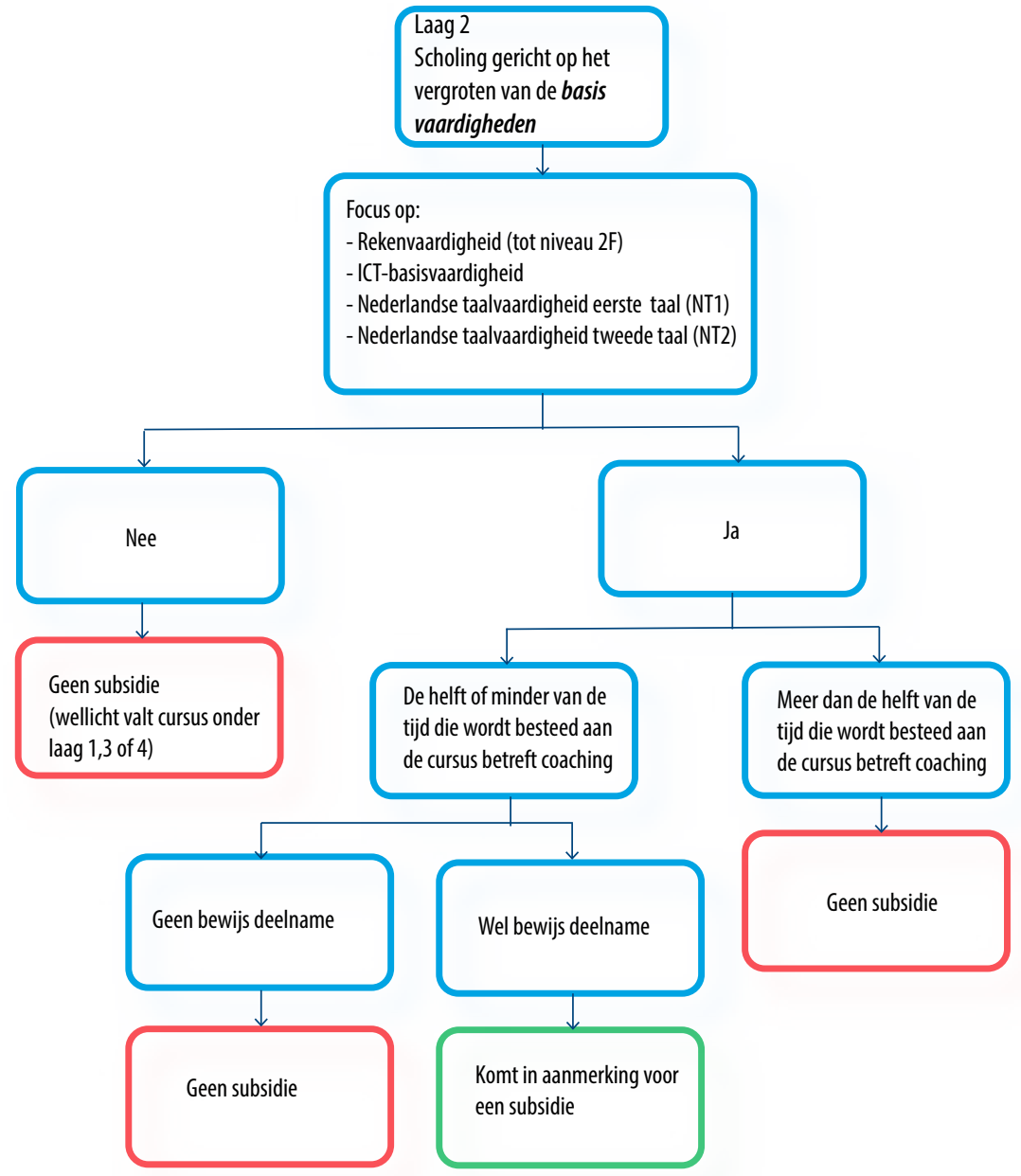




\section{Figuur 4}

Beslisboom: algemene inzetbaarheid op de arbeidsmarkt

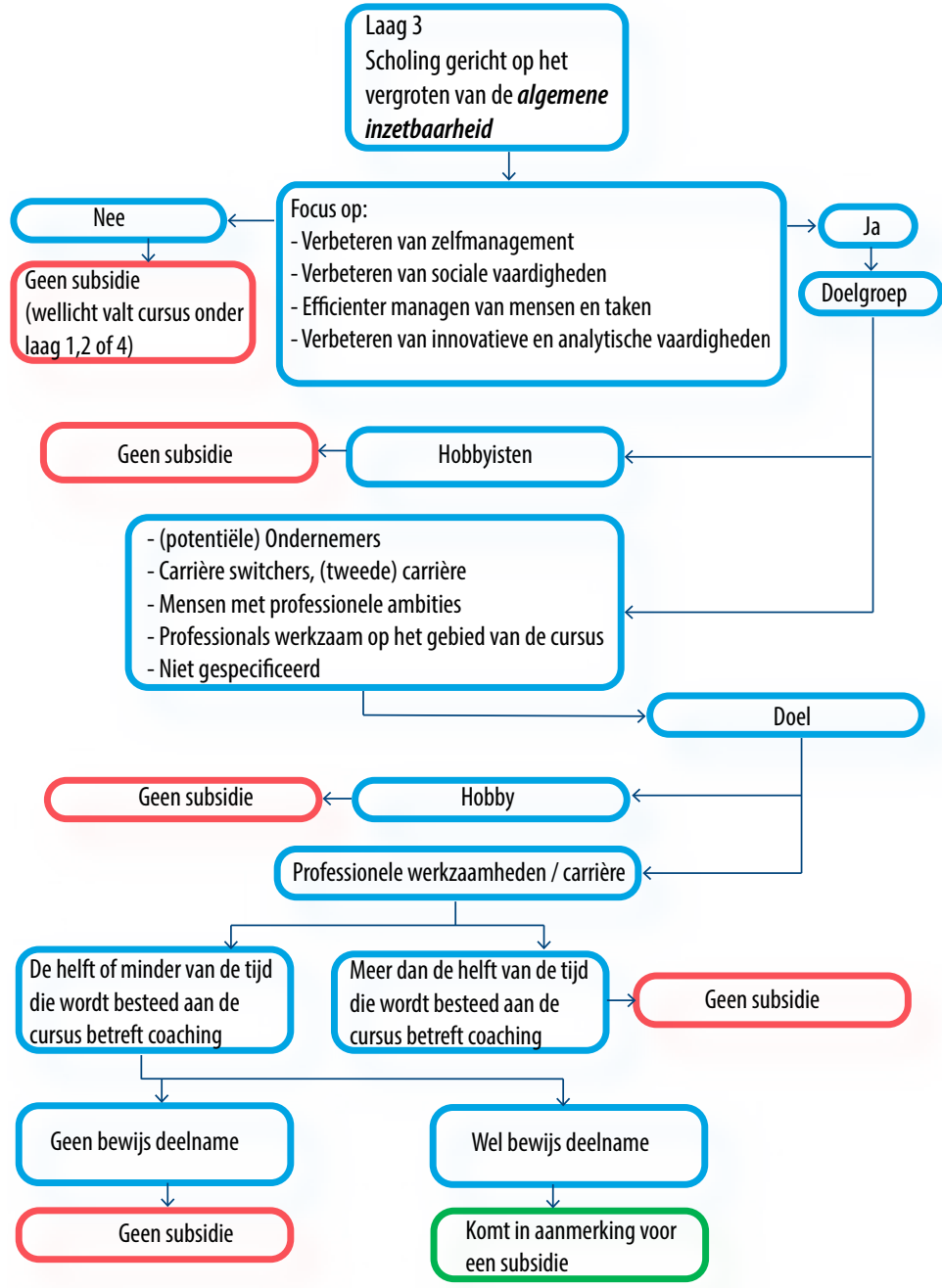




\section{Figuur 5}

Beslisboom: beroepsspecifieke vaardigheden

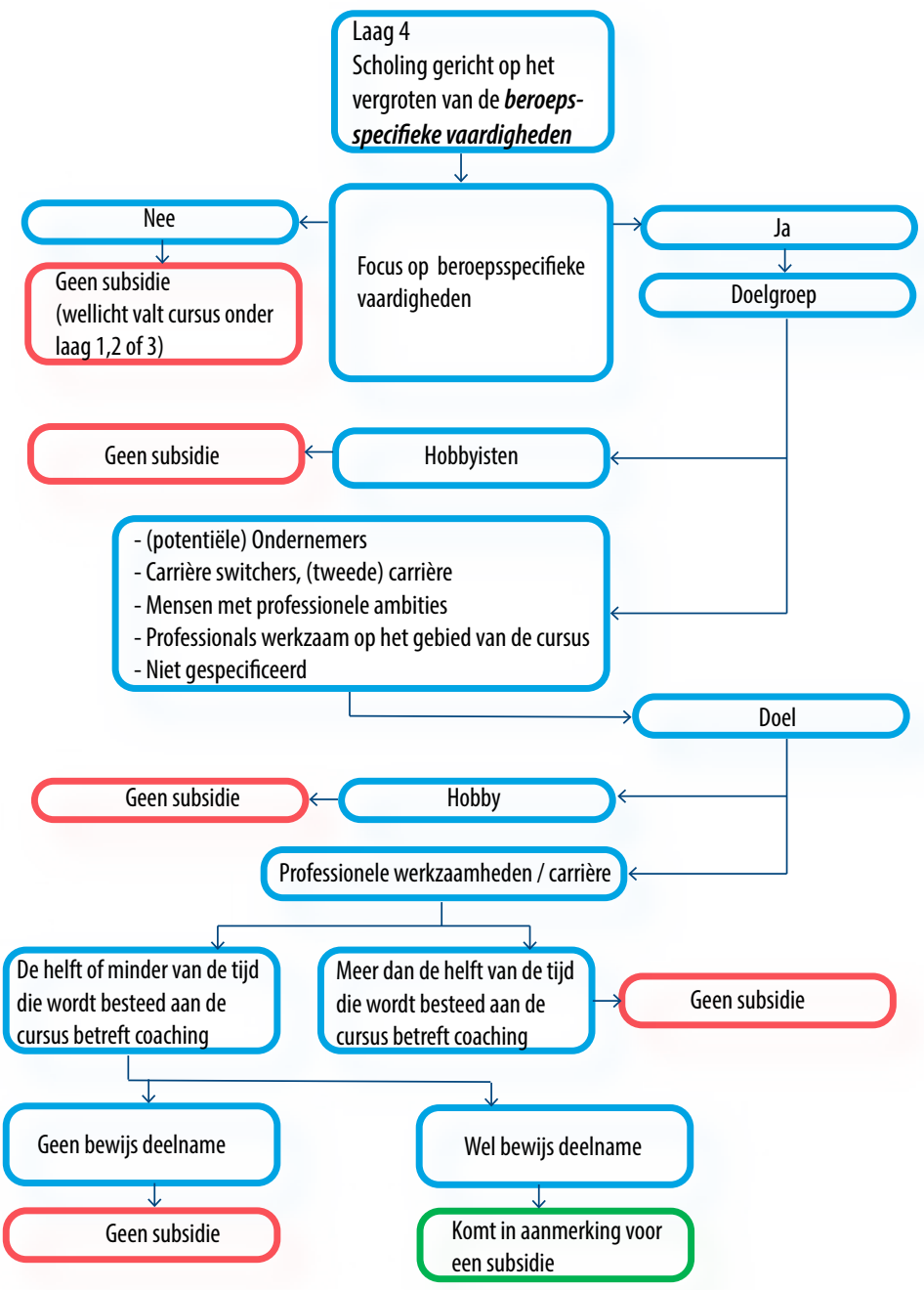





\section{Appendix B Voorbeelden doorlopen beslisbomen}

In deze appendix zijn een aantal voorbeelden van cursusbeschrijvingen opgenomen. Met kleuren is aangegeven of de scholing al dan niet voldoet aan de voorwaarden opgenomen in de beslisbomen. De voorbeelden zijn los gebaseerd op bestaand opleidingsaanbod.

\section{Voorbeeld 1. Cursus persoonlijke ontwikkeling}

De volgende informatie is beschikbaar over deze cursus:

- Tak 1. Scholing gericht op: De cursus Persoonlijke ontwikkeling geeft de cursist meer inzicht in het hoe en waarom achter verschillende onderwerpen. Wat je leert wordt meteen toegepast in opdrachten. Er zijn twee modules:

1. Zelfonderzoek en reflectie - basis

Tijdens deze module leert de cursust kritisch naar zichelf en haar / zijn ontwikkeling te kijken. Wat zijn je eigen waarden, overtuigingen en houdingen en welke invloed hebben deze op anderen. Ook leert de cursist om te gaan met culturele, religieuze en sekseverschillen en werkt deze aan haar / zijn communicatievaardigheden, het ontvangen van feedback en het leren reflecteren op je eigen handelen. $\mathrm{Na}$ afronding van deze module heeft de cursist geleerd om regelmatig te reflecteren op eigen gedrag én om zichzelf doorlopend te blijven ontwikkelen.

2. Persoonlijke ontwikkeling

Tijdens deze praktische module leert men op een diepgaand niveau naar ziczelf te kijken. Men neemt het leven onder de loep aan de hand van drie deelgebieden: het persoonlijke, het relationele en het professionele leven. Men wordt gestimuleerd om na te denken waarom men bepaalde keuzes maakt en hoe men daar verandering in aan kan brengen. De module leert concrete doelen te stellen en om een actieplan opstellen. Ter afronding van de module kies je één van de drie deelgebieden en daarvoor werk je een volledig actieplan uit. Zo leer je reflecteren, realistische doelen stellen, mogelijkheden te zien en hier een plan voor maken.

$$
\begin{aligned}
& \rightarrow \text { Scholing valt onder laag } 1 \text { Het vergroten van het leervermogen } \\
& \rightarrow \text { In het bijzonder onder scholing gericht op het vergroten van het zelfbeeld. }
\end{aligned}
$$

- Tak 2. Coaching component: Deze thuisstudie biedt alle ruimte om de opleiding goed te kunnen combineren met een baan en druk privéleven. De hele studiemethode is opgezet om flexibel en tegelijkertijd zeer doelgericht en zelfstandig 
te studeren. Daarbij krijg je online persoonlijke begeleiding door een docent met ruime ervaring in het vakgebied van je opleiding. Je kan altijd bij je docent terecht. De docent geeft antwoord op je vragen, feedback op je opdrachten en extra uitleg waar nodig via internet waarbij de nadruk wel ligt op zelfstudie.

$\rightarrow$ Coaching betreft maximaal de helft van de scholingstijd.

Conclusie voorbeeld 1: cursus kan opgenomen worden in het scholingsregister van STAP.

Voorbeeld 2. Slim leren op de werkplek

De volgende informatie is beschikbaar over deze cursus:

- Tak 1. Scholing gericht op: het verkrijgen van inzicht in je wendbaarheid met behulp van de Learning Agility Scan ${ }^{\circledR}$. Learning Agility staat voor het leer- en verandervermogen. Men leert de kracht van haar / zijn eigen veranderstijl te kennen en de cursus leert mensen hoe ze die optimaal kunnen benutten. Het doel van de cursus is om de totale wendbaarheid te versterken waardoor men sneller succesvol zult zijn. Men gaat met meer zelfvertrouwen om met veranderingen.

$\rightarrow$ Scholing valt onder laag 1 Het vergroten van het leervermogen
$\rightarrow$ In het bijzonder onder scholing gericht op het vergroten van het zelfbeeld.

- Tak 2. Coaching component: Tijdens de training onderzoek je samen met de trainer de resultaten van jouw Learning Agility Scan ${ }^{\oplus}$. Waar ligt je veranderkracht en hoe kun je die maximaal benutten? En hoe versterk je jezelf op andere punten? Dat doe je met heel praktische oefeningen, waarbij creativiteit en flexibiliteit centraal staan. De training vindt klassikaal plaats omdat je binnen een groep veel van elkaar leert.

$\rightarrow$ Coaching betreft minder dan de helft van de scholingstijd.

Conclusie voorbeeld 2: cursus kan opgenomen worden in het scholingsregister van STAP.

Voorbeeld 3. Persoonlijke stressbestendigheid

De volgende informatie is beschikbaar over deze cursus: 
- Tak 1. Scholing gericht op: Het verkrijgen van inzicht in stress en hoe je op een goede manier met stressvolle situaties omgaat.

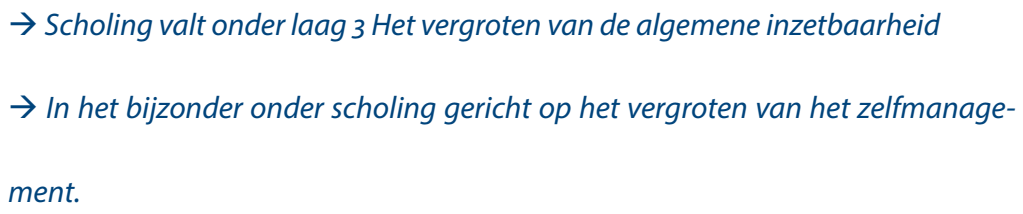

- Tak 2. Doelgroep: Voor iedereen die last heeft van stress en besloten heeft daar wat aan te doen.

$\rightarrow$ Niet gespecificeerd.

- Tak 3. Doel: Ben je druk op je werk en kun je thuis maar moeilijk ontspannen en daardoor moe of geïrriteerd? Heb je twijfels of je alles draaiende kan houden? Voorkom ongezonde spanning en stress door deze training te volgen. Je krijgt inzicht in stress en op manieren hoe je zo optimaal mogelijk met stressvolle situaties om kan gaan en jouw eigen gedrag. Zo leer je om proactief om te gaan met stressvolle situaties en blijf je stress de baas.

\section{$\rightarrow$ Professionele werkzaamheden/carrière}

- Tak 4. Coaching component: Met opdrachten ga je aan de slag met het doorbreken van je stresspatroon. Verder oefen je met technieken om je stressbestendigheid te vergroten, zoals mindfulness en timemanagement. Je legt dit allemaal vast in je eigen persoonlijke actieplan.

$\rightarrow$ Coaching betreft minder dan de helft van de scholingstijd.

Conclusie voorbeeld 3: cursus kan opgenomen worden in het scholingsregister van STAP.

Voorbeeld 4. Persoonlijke coaching

De volgende informatie is beschikbaar over deze cursus:

- Tak 1. Scholing gericht op: Heeft u behoefte aan een specifieke aanpak van uw persoonlijke knelpunten in uw werk? Wilt u doelgericht problemen aanpakken? Samen met $\mathrm{u}$ wordt er gekeken naar de punten die op dit moment voor $\mathrm{u}$ belang- 
rijk zijn om te verbeteren. Dit doen we door uw zelfbeeld vergroten en persoonlijke groei te stimuleren.

$\rightarrow$ Scholing valt onder laag 1

- Tak 2. Coaching component De training vindt plaats door middel van coaching Door middel van het stellen van specifieke vragen maakt de coach een pasklaar programma dat specifiek gericht is op $u$ en de situatie die u wenst aan te pakken. Alles is bespreekbaar of dat nu privé of zakelijk is. De persoonlijke aanpak is altijd gericht op de directe toepasbaarheid in uw bedrijf zodat u het geleerde ook meteen in de praktijk kan brengen.

$\rightarrow$ Coaching betreft meer dan de helft van de scholingstijd

Conclusie voorbeeld 4: cursus kan niet opgenomen worden in het scholingsregister van STAP.

Voorbeeld 5. Cursus broodbakken

De volgende informatie is beschikbaar over deze cursus:

- Tak 1. Scholing gericht op: De cursus broodbakker richt zich op thuisbakkers (in wording) en maakt je wegwijs in de wereld van het brood en de grondstoffen. Het doel van de cursus is iedereen enthousiast en bekwaam te maken, zodat je thuis in staat bent een goed brood te bakken

$\rightarrow$ Scholing valt buiten het kader, omdat het zich richt op hobbyisten.

Conclusie voorbeeld 5: cursus kan niet opgenomen worden in het scholingsregister van STAP.

Voorbeeld 6. Computervaardigheden

De volgende informatie is beschikbaar over deze cursus:

- Tak 1. Scholing gericht op: Na afloop van de cursus kun je zelfstandig en veilig omgaan met veelvoorkomende computerfuncties. Je doet alle kennis en vaardigheden op die je nodig hebt op het gebied van computers. Dit is niet alleen van belang voor je werk, maar ook in het dagelijks leven. 
$\rightarrow$ Scholing valt onder laag 2 Het vergroten van basisvaardigheden, in het bijzonder ICT-basisvaardigheid

Conclusie voorbeeld 6: cursus kan opgenomen worden in het scholingsregister van STAP. 
